\title{
Effect of Different Doses of Gamma Irradiation on Vegetative Growth and Oil Yield of Ocimum basilicum $\mathrm{L}$. Shala, A. Y. \\ Medicinal and Aromatic Plants Research Department, Horticulture Research Institute. Agricultural Research Center, Giza, Egypt. E-mail address awad.shala@yahoo.com
}

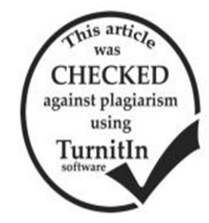

ABSTRACT

Gamma irradiation is important agent used to improve the productivity and quality of many plants. The present study was carried out to evaluate the effectiveness of different doses of gamma rays $(0,5,10,15,20,25,30 \mathrm{kR})$ on germination percentage, vegetative growth, photosynthetic pigments, oil yield, oil components and total phenolic content of Ocimum basilicum L during the two successive seasons of 2017 and 2018 at the Experimental Farm of Sakha Horticulture Research Station, Kafr El-Sheikh Governorate, Egypt. Results showed that low doses of gamma irradiation significantly increased germination percentage, plant height, number of branches, fresh and dry weight per plant and per fed, chlorophyll a and chlorophyll b, essential oil percentage, oil yield per plant and per fed and essential oil main components. Increasing gamma rays doses significantly reduced germination percentage, vegetative growth characters and oil yield while total carotenoids content and total phenolic content significantly increased as a defensive effect to the increase in irradiation doses. The study suggested $10 \mathrm{kR}$ dose as seeds treatment for increasing basil plants production through enhancing germination percentage, vegetative growth, fresh yield, essential oil yield and essential oil components.

Keywords: Irradiation, Ocimum basilicum L, Phenolic content, Essential oil

\section{INTRODUCTION}

Basil (Ocimum basilicum L.) is a member of the Lamiaceae Family, which is a widely cultivated aromatic crop grown either for the production of essential oil, dry leaves for the market or as an ornamental (Simon et al., 1990). Basil includes annual and perennial herbs, and shrubs native to the tropical and subtropical areas of Asia, Africa and South America (Darrah, 1988). Almost 60 species of basil are recognized all over the world and widely planted in France, Egypt, Hungary, Indonesia, Morocco, The United States, Greece and Israel (Srivastava, 1980). Both the fresh and dry leaves of the plant are consumed in the food and spice industries. Additionally, it is also has been used for headaches, coughs, worms, stomach-ache and kidney malfunctions in medical therapies (Simon et al., 1990). Furthermore, it is also deemed as a source of aroma combinations and accordingly, owns a range of biological properties such as insect repellent, nematocidal, antibacterial, antifungal agents and antioxidant properties (Deshpande and Tipnis, 1977, Simon et al., 1990 and Juliani and Simon, 2002).

Gamma radiation, more energetic than X-rays, is implemented from sources of radioactive isotopes, cesium137 or cobalt-60, and it is specified by the World Health Organization as a food preservation technique that enhances food safety without modifying the toxicological, biological or nutritional quality of the food (Diehl, 2002, Datta, 2009 and Farkas and Mohácsi-Farkas, 2011). Furthermore, (Mokobia and Anomohanran, 2005) indicated that gamma irradiation were beneficial not only for sterilization of medicine but also for the preservation of food and cereals in nutrition and agriculture. Irradiation was successfully applied to solve many agricultural problems: reduction of post-harvest losses (Villavicencio et al., 2018) and enhancement salt stress tolerance (Pimonrat and Yi, 2017 and Aly et al., 2018). Additionally, It is one of the important physical agents utilized to enhance the quality of medicinally valuable plants, including their biomass production (Hamideldin and Eliwa, 2015, Verma et al., 2017 and Masoud et al., 2018) through prompting cytological, genetical, biochemical, physiological and morphogenetic variations in cells and tissues relying on the irradiation level (Datta, 2009). Due to the low wavelength with elevated penetrable power of gamma rays, its interaction with atoms or molecules to generate free radicals in the cells. Free radicals have been informed to induce changes in cellular structure and metabolism, e.g. dilation of thylakoid membranes, alteration in photosynthesis, modulation of antioxidative system and accumulation of phenolic compounds (Wi et al., 2007 and Masoud et al., 2018 and Villavicencio et al., 2018).

Plant phenolics are commonly involved in protection versus ultraviolet radiation or attack by pathogens, parasites and predators, as well as contributing to plants (Dai and Mumper, 2010). It has been reported that total flavonoids as a group of phenolics responded significantly to gamma radiation doses particularly $64 \mathrm{k}$ rad in different dill plant parts (Said-al Ahl et al., 2015).

Likewise, (Masoud et al., 2018) stated that 40 Gy dose increased accumulation of total phenolic compounds in Cichorium pumilum Jacq. roots also, gamma rays at 600Gy produced the highest phenol content of Abelmoschus moschatus (Suneetha et al., 2018). The importance of phenols for plants is due to a fair correlation among antioxidant/free-radical scavenging activity and its phenolic content. Furthermore, phenol compounds are thought to protect the plant against irradiation-induced oxidative stress (Masoud et al., 2018).

Regarding Ocimum basilicum, no published literature exists about the impact of gamma irradiation treatments on changes in its phenolic content and essential oil yield. Accordingly, the aim of the current work is to study the influence of different doses of gamma irradiation on germination, vegetative growth, potential changes in the total phenolic content and oil percentage as well as oil components of Ocimum basilicum L. plants.

\section{MATERIALS AND METHODS}

Seeds of sweet basil (Ocimum basilicum L.) were acquired from Medicinal and Aromatic plants Research Department, Horticulture Research Institute, Agriculture Research Center, Giza, Egypt. 500 dry seeds were subjected to $0,5,10,15,20,25,30 \mathrm{krad}(\mathrm{kR})$ gammairradiation doses using cobalt-60 with dose rate of $3.58 \mathrm{~min}$ $/ 10 \mathrm{kR}$ at the National Center for Radiation Research and Technology, Atomic Energy Authority, Nasr City, Cairo, Egypt.

The irradiated and non-irradiated seeds were sown in the greenhouse on $1^{\text {st }}$ and $3^{\text {rd }}$ March 2017 and 2018 seasons respectively into a combination of vermiculite and peat moss $(2: 1)$, the seedlings were transplanted on $15^{\text {th }}$ 
and $17^{\text {th }}$ April 2017 and 2018 respectively on $30 \mathrm{~cm} \times 60$ $\mathrm{cm}$ plant spacing at the Experimental Farm of Sakha Horticulture Research Station Kafr El-Sheikh, Egypt on a complete randomized blocks design with three replications.

The soil of the experimental site was clay texture and it contained $54.10 \%$ clay, $26.30 \%$ silt and $19.60 \%$ sand. The electrical conductivity (EC) and $\mathrm{pH}$ of the soil in the saturated soil paste were 2.65 and $8.15 \mathrm{dSm}^{-1}$, respectively as mean of $0-60 \mathrm{~cm}$ depth all chemical and physical properties were determined according to Page et al. (1982). All agricultural practices were done according to the Ministry of Agriculture and Land Reclamation recommendation.

Seeds germination percentage, was recorded after one week from germination which estimated by using this formula

Germination(\%) $\frac{\text { Number of seeds germinated }}{\text { Total number of seeds sown for germination }} \times 100$

Determination of photosynthetic pigments, chlorophyll a, b and total carotenoids content were evaluated in fresh leaves for both cuts of two seasons by the spectrophotometric method recommended by (Lichtenthaler and Buschmann, 2001). The pigment contents were assessed as $\mathrm{mg} / \mathrm{cm}^{2}$ fresh weight

Plants were harvested on July $15^{\text {th }}$ and September $15^{\text {th }}$ in 2017 and 2018 seasons respectively then the following data were registered: plant height $(\mathrm{cm})$, number of main branches, plant fresh weight $(\mathrm{g})$, plant dry weight $(\mathrm{g})$ and fresh herb yield ( $\mathrm{t} / \mathrm{fed}$.)

Herb essential oil percentage, plants were harvested and $100 \mathrm{gm}$ fresh herb was utilized to a $3 \mathrm{~h}$ hydrodistillation apparatus according to (Pharmacopoeia, 1963). The essential oil ratio of the plants was reported by a volumetric method $(\mathrm{ml} / 100 \mathrm{~g})$ then oil yield per plant as well as per fed(l) was calculated and the isolated essential oil was retained at $4 \mathrm{C}$ o until the gas chromatography analysis which was performed at Medicinal and Aromatic Plants Research Department Lab., Horticulture Research Institute, Giza, Egypt that was examined by DsChrom 6200 Gas Chromatograph prepared with a flame ionization detector for separation of volatile oil constituents. The analysis conditions were as follows: The chromatograph apparatus was connected with capillary column BPX-5, $5 \%$ phenyl (equiv.) polysillphenylene -siloxane $30 \mathrm{~m} \mathrm{x}$ $0.25 \mathrm{mmID} \times 0.25 \mu \mathrm{m}$ film. Temperature program ramp rise with average of $10 \mathrm{C} / \mathrm{min}$ from 70 to $200 \mathrm{C}^{\mathrm{o}}$. Flow rates of gases were nitrogen at $1 \mathrm{ml} / \mathrm{min}$, hydrogen at $30 \mathrm{ml} / \mathrm{min}$ and $330 \mathrm{ml} / \mathrm{min}$ for air. Temperatures of detector and injector were $300 \mathrm{C}^{\circ}$ and $250 \mathrm{C}^{\circ}$, respectively. The acquired chromatogram and report of $\mathrm{GC}$ analysis were analyzed to evaluate the percentage of essential oils main components.

Total phenolic content was evaluated quantitatively according to the method illustrated by (Jindal and Singh, 1975). A standard curve was made by using several concentrations of gallic acid and utilized for the determination of total phenolic content (mg/g d.wt).

Statistical analysis of variance (ANOVA) was conducted using COSTAT software. Differences between treatments means were carried out by Duncan's multiple range test (Snedecor and Cochran, 1980).

\section{RESULTS AND DISCUSSION}

\section{Germination percentage}

The lower gamma irradiation doses (5 and 10kR) noticeably stimulated basil seed germination while, increased doses of gamma rays treatment (15 to $30 \mathrm{kR}$ ) significantly reduced germination percentage as compared to control plants during both seasons (Fig., 1). These findings are consistent with the results presented by (Bhosale and More, 2014) on Withania somnifera, L., (Bhat et al., 2016) on Linum usitatissimum L., (Verma et al., 2017) on Foeniculum vulgare Mill. and Bhala and Verma, (2018) on Solanum lycopersicum that high levels of gamma irradiation had deleterious effects on seed germination percentage. The reduction in seed germination at raised doses of gamma irradiation could be due to the injury in seed tissue, chromosomes and subsequent mitotic retardation and the severity of the damage depend on the applied doses (Datta, 2009). Additionally disturbs the synthesis of protein, hormone balance, gas- exchange, water exchange and enzyme activity (Hameed et al., 2008).

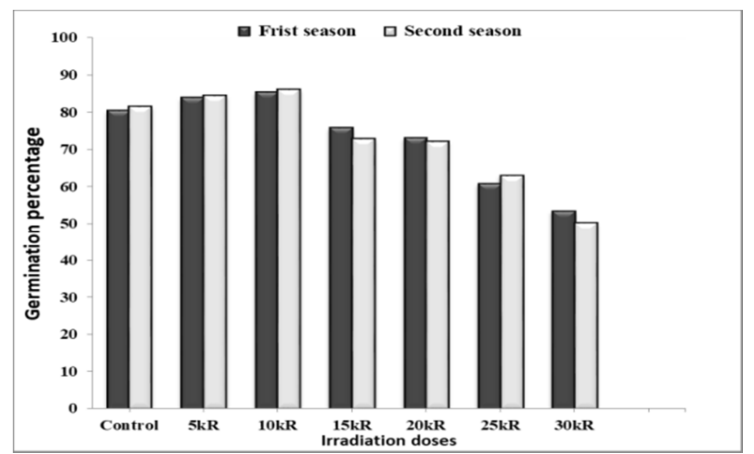

Fig. 1. Effect of different doses of gamma irradiation on seeds germination percentage of Ocimum basilicum L. during both seasons of 2017 and 2018.

\section{Vegetative growth characteristics}

Increasing gamma irradiation doses significantly decreased plant height, the highest plants were reported for control and treated plants with $5 \mathrm{kR}$ respectively without significant differences between them in the first cut only while control plants recorded the greatest values for plant height in the second cut of both growing seasons (Table, 1). These remarks were in accordance with Bhosale and More (2014) who noticed a gradual decrease in Withania somnifera seedling height when gamma rays increased from 10 to 40kR, Khan et al.(2014) treated seeds of Brassica napus L. by gamma rays doses ( 0, 10, 15, 20, 25 and 30kR) and exhibited that elevated doses of radiation markedly reduced plant height compared with control. Similarly, Verma et al.(2017) stated that all levels of gamma rays $(15,17.5,20,22.5$ and $25 \mathrm{kR})$ reduced the fennel seedling height. The decline in plant height because of high irradiation doses can be attributed to minimize in mitotic activity of meristematic tissues and decreased seeds moisture content.

The maximum number of branches were noticed for plants irradiated with $10 \mathrm{kR}$ followed by $5 \mathrm{kR}$ without significant differences among them in the first cut of the first season only as compared with un-irradiated plants (Table, 1). These outcomes were in harmony with the observation of Hamideldin and Eliwa,(2015) in which branches number of mustard plants were progressively increased with rising gamma irradiation doses from 10 to 50Gy. Moreover, branches number were significantly diminished with raising gamma rays doses therefore, the least branches number was recorded for irradiated basil plants with $30 \mathrm{kR}$. A reduction in branches number for several crops that were subjected to elevated gamma-ray doses had been previously reported ( Khan et al., 2014 and Verma et al., 2017). 
Table 1. Effect of various doses of gamma irradiation on plant height, main branches number, fresh and dry weight (g/plant) and fresh yield (t/fed.) of Ocimum basilicum L. during the two cuts of both seasons 2017 and 2018.

\begin{tabular}{|c|c|c|c|c|c|c|c|c|c|}
\hline \multirow[b]{3}{*}{ Dose (kR) } & \multicolumn{8}{|c|}{$1^{\text {st }}$ Season 2017} & \multirow[b]{3}{*}{$\begin{array}{c}\text { Fresh yield } \\
\text { (t/fed.) }\end{array}$} \\
\hline & \multicolumn{4}{|c|}{$1^{\text {st }}$ cut } & \multicolumn{4}{|c|}{$2^{\text {nd }}$ cut } & \\
\hline & $\begin{array}{c}\text { Plant } \\
\text { height }(\mathrm{cm})\end{array}$ & $\begin{array}{c}\text { Branches } \\
\text { No. }\end{array}$ & $\begin{array}{c}\text { Fresh } \\
\text { weight (g) }\end{array}$ & $\begin{array}{c}\text { Dry } \\
\text { weight (g) }\end{array}$ & $\begin{array}{c}\text { Plant } \\
\text { height }(\mathrm{cm})\end{array}$ & $\begin{array}{c}\text { Branches } \\
\text { No. }\end{array}$ & $\begin{array}{c}\text { Fresh } \\
\text { weight }(g)\end{array}$ & $\begin{array}{c}\text { Dry } \\
\text { weight }(\mathrm{g})\end{array}$ & \\
\hline$\overline{\text { Control }}$ & $70.66 \mathrm{a}$ & $13.66 \mathrm{ab}$ & $221.53 \mathrm{~b}$ & $71.32 b$ & $74.66 \mathrm{a}$ & $15.00 \mathrm{c}$ & $300.00 \mathrm{c}$ & $95.41 \mathrm{c}$ & $11.59 \mathrm{~b}$ \\
\hline $5 \mathrm{kR}$ & $70.66 \mathrm{a}$ & $13.00 \mathrm{abc}$ & $266.74 a$ & $87.75 \mathrm{a}$ & $67.33 \mathrm{~b}$ & $16.66 \mathrm{~b}$ & $347.90 \mathrm{~b}$ & $115.33 b$ & $13.66 \mathrm{a}$ \\
\hline $10 \mathrm{kR}$ & $66.66 \mathrm{~b}$ & $14.33 \mathrm{a}$ & $260.51 \mathrm{a}$ & $82.11 \mathrm{a}$ & $60.66 \mathrm{c}$ & $22.00 \mathrm{a}$ & $377.20 \mathrm{a}$ & $121.05 \mathrm{a}$ & $14.17 \mathrm{a}$ \\
\hline $15 \mathrm{kR}$ & $61.00 \mathrm{c}$ & $10.66 \mathrm{bcd}$ & $182.86 \mathrm{c}$ & $62.43 b c$ & $58.00 \mathrm{~d}$ & $11.33 \mathrm{~d}$ & $272.90 \mathrm{~d}$ & $72.62 d$ & $10.11 \mathrm{c}$ \\
\hline $20 \mathrm{kR}$ & $58.00 \mathrm{~cd}$ & $9.66 \mathrm{~cd}$ & $168.40 \mathrm{~cd}$ & $58.61 \mathrm{c}$ & d & $12.66 \mathrm{~d}$ & $0 \mathrm{e}$ & $1 d$ & $5 c$ \\
\hline $25 \mathrm{kR}$ & $55.33 \mathrm{de}$ & $9.66 \mathrm{~cd}$ & $165.85 \mathrm{~cd}$ & $48.73 \mathrm{~d}$ & $54.50 \mathrm{e}$ & $11.33 \mathrm{~d}$ & $242.04 f$ & $52.08 \mathrm{f}$ & $9.64 \mathrm{~d}$ \\
\hline $30 \mathrm{kR}$ & $54.00 \mathrm{e}$ & $7.66 \mathrm{~d}$ & $140.00 \mathrm{~d}$ & $42.40 \mathrm{~d}$ & $51.00 \mathrm{f}$ & $9.33 \mathrm{e}$ & $230.53 \mathrm{~g}$ & $57.54 \mathrm{e}$ & $8.23 \mathrm{e}$ \\
\hline \multicolumn{10}{|c|}{$2^{\text {nd }}$ Season 2018} \\
\hline Control & $71.63 \mathrm{a}$ & $14.64 a b$ & $222.50 \mathrm{~b}$ & $70.37 b$ & $73.69 \mathrm{a}$ & $15.95 \mathrm{c}$ & $289.04 c$ & $93.41 \mathrm{c}$ & $11.37 \mathrm{~b}$ \\
\hline $5 \mathrm{kR}$ & $71.63 \mathrm{a}$ & $13.98 \mathrm{abc}$ & $267.70 a$ & $86.81 \mathrm{a}$ & $66.36 \mathrm{~b}$ & $17.61 \mathrm{~b}$ & $336.94 b$ & $113.32 b$ & $13.44 \mathrm{a}$ \\
\hline $10 \mathrm{kR}$ & $67.63 a$ & $15.31 \mathrm{a}$ & $261.48 \mathrm{a}$ & $81.16 \mathrm{a}$ & $59.69 \mathrm{c}$ & $22.95 \mathrm{a}$ & $366.24 a$ & $119.04 a$ & $13.95 \mathrm{a}$ \\
\hline $15 \mathrm{kR}$ & $61.96 \mathrm{~b}$ & $11.64 \mathrm{bc}$ & $187.70 \mathrm{c}$ & $61.48 \mathrm{bc}$ & $57.02 \mathrm{~d}$ & $12.28 \mathrm{de}$ & $255.04 d$ & $70.61 d$ & $9.75 \mathrm{~d}$ \\
\hline $20 \mathrm{kR}$ & $58.97 \mathrm{~b}$ & $7.95 \mathrm{~d}$ & $183.83 \mathrm{c}$ & $57.66 \mathrm{c}$ & $53.62 \mathrm{e}$ & $13.61 d$ & $212.75 \mathrm{e}$ & $67.95 \mathrm{e}$ & $8.90 \mathrm{~d}$ \\
\hline & $53.96 \mathrm{c}$ & $10.64 \mathrm{~cd}$ & $161.82 \mathrm{~cd}$ & $49.45 \mathrm{~cd}$ & $50.53 \mathrm{f}$ & $10.75 \mathrm{e}$ & $213.91 \mathrm{e}$ & $50.08 \mathrm{~g}$ & $8.34 \mathrm{e}$ \\
\hline $30 \mathrm{kR}$ & $54.96 \mathrm{c}$ & $8.64 \mathrm{~cd}$ & $140.97 d$ & $41.45 \mathrm{~d}$ & $50.02 \mathrm{f}$ & $10.75 \mathrm{e}$ & $201.72 f$ & $55.53 \mathrm{f}$ & $7.62 f$ \\
\hline
\end{tabular}

Means designed by the same letter at each column are not significantly different at the $5 \%$ level according to Duncan's multiple range test.

Fresh and dry weight (g/plant), as well as fresh yield ( $t /$ fed.) were significantly affected by gamma irradiation doses (Table, 1). The maximum values were recorded from plants irradiated with 5 and $10 \mathrm{kR}$ without significant variation between them in the first season only and $10 \mathrm{kR}$ in the second season. The greatest impact of gamma irradiation doses on total yield was in conformity with the previous results of Hamideldin and Eliwa, (2015) in which total biomass of mustard plants was significantly enhanced when gamma rays dose increased from 10 to 50 Gy. The stimulatory effect of 5 and $10 \mathrm{kR}$ dose on fresh and dry weight were because gamma rays promote the role of enzyme as well as growth hormone responsible for growth and yield (Wi et al., 2007). As the dose of gamma rays increased from 15 to $30 \mathrm{kR}$, there was a gradual decrease in the fresh, dry weight and total fresh yield of basil plants. These outcomes were in accordance with the observation of Bhat et al.(2016) who remarked that gamma rays at $15 \mathrm{kR}$ noticeably reduced dry weight of Linum usitatissimum L. plants. Likewise, Verma et al. (2017) noticed that about $50 \%$ reduction in fennel vegetative growth parameters were obtained at $20 \mathrm{kR}$ of gamma rays. The decrease in plants fresh and dry weights may be due to diminishing moisture content because of radiation stress especially when subjected to high doses of gamma rays.

\section{Photosynthetic pigments}

Irradiating plants with gamma rays at $10 \mathrm{kR}$ in the first cut and $15 \mathrm{kR}$ in the second cut for both growing seasons enhanced chlorophyll $a$ and $b$ contents as compared to control (Fig., 2). It was also observed that chlorophyll-a was greater than chlorophyll-b in each irradiated and non-irradiated plants. The present results are in conformity with the observations of Hamideldin and Eliwa,(2015) in which gamma irradiation increased photosynthetic pigments contents in the leaf of mustard plants also, Aly et al. (2018) reported that irradiated wheat plants with 100 and 200Gy of gamma rays improved photosynthetic pigment content under salt stress conditions. Increased chlorophylls by irradiation may be due to stimulation biosynthesis of chlorophyll and/or delaying of its degradation (Aly et al., 2018). Furthermore, alteration in photosynthesis in the irradiated plants maybe partly participates to increase growth (Wi et al., 2007). On the other hand, the higher dosage of gamma irradiation had recorded low chlorophyll content that was in conformity with the previous results of Suneetha et al.(2018) on Abelmoschus moschatus and Masoud et al. (2018) on Cichorium pumilum Jacq. Impact of gamma irradiation intensities on chlorophyll was assessed in terms of disturbed hormonal balance, leaf gas-exchange, water exchange and enzyme activity (Stoeva, 2002).

Concerning carotenoids content, increasing gamma irradiation levels from 5 to $30 \mathrm{kR}$ markedly increased carotenoids content of basil leaves (Fig., 2).The highest carotenoids content was achieved from plants irradiated with $30 \mathrm{kR}$ without significant differences between high irradiation dosages as compared with non-irradiated plants which recorded the lowest carotenoids content in both growing seasons. Increases in basil carotenoids content are a significant way to increase plant resistance to abiotic stresses (Shala and Mahmoud, 2018). Similar results were earlier reported by Masoud et al. (2018) in which carotenoids content increased as a defensive impact to the increase of gamma doses and the highest carotenoids content produced from irradiated chicory plants with 80Gy.

\section{Essential oil percentage and oil yield}

Oil percentage and oil yield/plant (ml) and/fed (l) were increased gradually at low doses of gamma irradiation the highest values were produced from irradiated plants with $10 \mathrm{kR}$ as compared with control treatment (Table, 2). Meanwhile, the least values for oil percentage and oil yield were obtained from irradiated plants with 25 and $30 \mathrm{kR}$ without significant differences among them in both seasons. Similar observations were formerly reported by Khan et al. ( 2014) who detected that oil content of Brassica napus L. considerably declined with high radiation doses (30kR). Likewise, Hamideldin and Eliwa, (2015) demonstrated that fatty acids contents of mustard seeds were changed by gamma irradiation doses and Masoud et al. (2018) suggested that gamma irradiation at $40 \mathrm{~Gy}$ was an effective dose to stimulate the metabolism and accumulation of active compounds of chicory plants. Gamma ray increase secondary metabolites yield by enhancing the activity of certain key biosynthetic enzymes as reported by Vardhan and Shukla, (2017). 

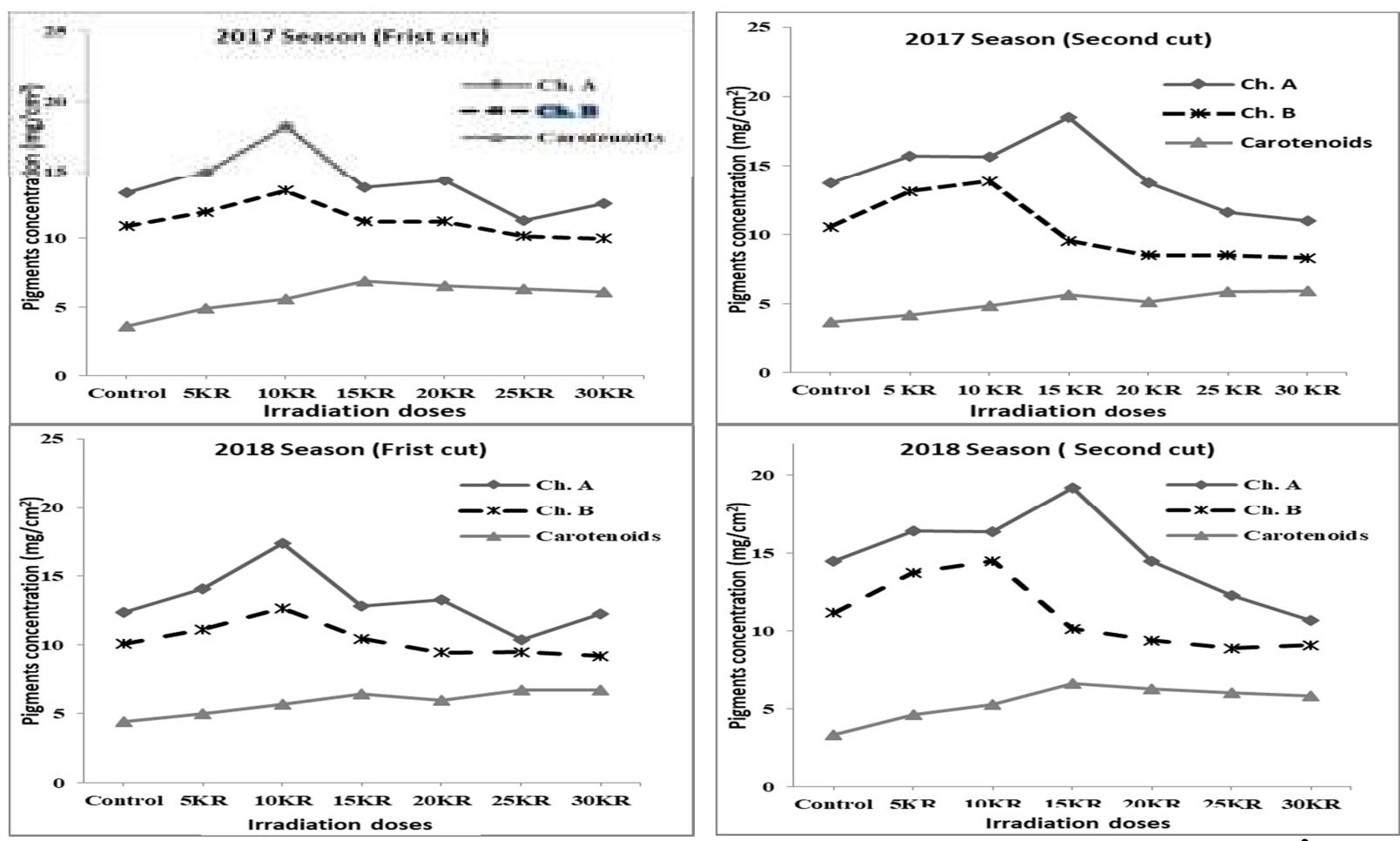

Fig. 2. Effect of different doses of gamma irradiation on chlorophyll a, $b$ and carotenoids content $\left(\mathrm{mg} / \mathrm{cm}^{2} F . W.\right) ~ o f$ Ocimum basilicum $\mathrm{L}$. during the two cuts of both seasons (2017/2018).

Table 2. Effect of different doses of gamma irradiation on oil percentage, oil yield/plant (ml) and oil yield /fed (l) of Ocimum basilicum L. during the two cuts of both seasons 2017 and 2018.

\begin{tabular}{|c|c|c|c|c|c|}
\hline \multirow[b]{3}{*}{ Dose (kR) } & \multicolumn{4}{|c|}{$1^{\text {st }}$ Season 2017} & \multirow[b]{3}{*}{ Oil yield (l/fed.) } \\
\hline & \multicolumn{2}{|c|}{$1^{\text {st }}$ cut } & \multicolumn{2}{|c|}{$2^{\text {nd }}$ cut } & \\
\hline & Oil percentage & Oil yield /plant(ml) & Oil percentage & Oil yield /plant(ml) & \\
\hline Control & $0.10 \mathrm{~d}$ & $0.22 \mathrm{~cd}$ & $0.15 \mathrm{c}$ & $0.45 \mathrm{~d}$ & $14.93 \mathrm{~d}$ \\
\hline $5 \mathrm{kR}$ & $0.16 \mathrm{~b}$ & $0.43 b$ & $0.19 b$ & $0.66 \mathrm{~b}$ & $24.16 b$ \\
\hline $10 \mathrm{kR}$ & $0.19 \mathrm{a}$ & $0.50 \mathrm{a}$ & $0.21 \mathrm{a}$ & $0.79 a$ & $28.61 \mathrm{a}$ \\
\hline $15 \mathrm{kR}$ & $0.13 \mathrm{c}$ & $0.24 \mathrm{c}$ & $0.20 \mathrm{ab}$ & $0.54 \mathrm{c}$ & $17.39 \mathrm{c}$ \\
\hline $20 \mathrm{kR}$ & $0.13 c$ & $0.22 \mathrm{~cd}$ & $0.13 d$ & $0.35 \mathrm{e}$ & $12.55 \mathrm{e}$ \\
\hline $25 \mathrm{kR}$ & $0.10 \mathrm{~d}$ & $0.17 \mathrm{de}$ & $0.10 \mathrm{e}$ & $0.24 \mathrm{f}$ & $9.06 \mathrm{f}$ \\
\hline $30 \mathrm{kR}$ & $0.11 \mathrm{~d}$ & $0.15 \mathrm{e}$ & $0.11 \mathrm{e}$ & $0.25 \mathrm{f}$ & $9.06 \mathrm{f}$ \\
\hline \multicolumn{6}{|c|}{$2^{\text {nd }}$ Season 2018} \\
\hline Control & $0.14 d$ & $0.31 \mathrm{~b}$ & $0.14 d$ & $0.40 \mathrm{~d}$ & $15.92 \mathrm{c}$ \\
\hline $5 \mathrm{kR}$ & $0.18 \mathrm{a}$ & $0.48 \mathrm{a}$ & $0.20 \mathrm{~b}$ & $0.67 b$ & $25.67 b$ \\
\hline $10 \mathrm{kR}$ & $0.18 \mathrm{a}$ & $0.47 \mathrm{a}$ & $0.23 \mathrm{a}$ & $0.84 \mathrm{a}$ & $29.20 \mathrm{a}$ \\
\hline $15 \mathrm{kR}$ & $0.16 b$ & $0.29 b$ & $0.18 \mathrm{c}$ & $0.46 \mathrm{c}$ & $16.75 \mathrm{c}$ \\
\hline $20 \mathrm{kR}$ & $0.15 \mathrm{c}$ & $0.28 b$ & $0.11 \mathrm{f}$ & $0.23 \mathrm{e}$ & $11.46 \mathrm{~d}$ \\
\hline $25 \mathrm{kR}$ & $0.12 \mathrm{e}$ & $0.20 \mathrm{c}$ & $0.12 \mathrm{ef}$ & $0.26 \mathrm{e}$ & $10.25 \mathrm{e}$ \\
\hline $30 \mathrm{kR}$ & $0.13 \mathrm{e}$ & $0.18 \mathrm{c}$ & $0.13 \mathrm{de}$ & $0.26 \mathrm{e}$ & $9.90 \mathrm{e}$ \\
\hline
\end{tabular}

Means designed by the same letter at each column are not significantly different at the $5 \%$ level according to Duncan's multiple range test.

\section{Essential oil components}

Gas chromatographic analysis for basil essential oil detected the existence of 22 compounds of them 14 components were distinguished by the retention times acquired from pure reference compounds (Table, 3). The defined components were linalool and eugenol as a main components followed by 1.8 cineole, borneol, camphor, $\alpha$ terpineol, methyl chavicole, terpinene-4-ol, terpinolene, $\beta$ pinene, bornyl-acetate, $\alpha$-pinene, camphene and $\beta$ caryophyllene while rest of the compounds were unknown.

Our obtained data pointed out that the relatively low doses of gamma rays (10kR) markedly increased $\alpha$ pinene, camphene, $\beta$ - pinene, 1.8 cineole, linalool and eugenol as compared to control but some components like methyl chavicole was decreased as compared to all treatments that might nominate $10 \mathrm{kR}$ to be the optimum dose for increasing basil essential oil components. While, the highest percentage from terpinene-4-ol, borneol, $\alpha$ terpineol and $\beta$-caryophyllene were obtained from plants irradiated with $15 \mathrm{kR}$ as compared to un-irradiated plants however, camphor disappeared at the same dose and 20kR but increased at $5 \mathrm{kR}$. On the other hand, terpinolene declined at all doses as compared to control. These results are supported by the previous study on Brassica alba (Hamideldin and Eliwa, 2015) who noticed that low doses of gamma radiation (10 and 20Gy) increased oleic and linoleic acid contents, whereas a decrease was obtained in response to seed treatments with the relatively higher doses $(30,40,50 \mathrm{~Gy})$ as compared to control. On contrary, Erucic acid increased in response to the highest dose of gamma radiation (50Gy) and decreased particularly at lower doses. 
Table 3. Effect of different doses of gamma irradiation on basil essential oil components in the second season of 2018

\begin{tabular}{|c|c|c|c|c|c|c|c|}
\hline Components name & Control & $5 \mathbf{k R}$ & $10 \mathrm{kR}$ & $15 \mathrm{kR}$ & 20kR & $25 \mathrm{kR}$ & $30 \mathrm{kR}$ \\
\hline$\alpha$-Pinene & 0.39 & 0.27 & 0.73 & 0.18 & 0.16 & ---- & 0.23 \\
\hline Camphene & 0.22 & 0.35 & 0.40 & 0.12 & - & 0.39 & 0.56 \\
\hline$\beta$-Pinene & 1.11 & 0.89 & 1.11 & 0.85 & 0.82 & 1.07 & 0.98 \\
\hline 1.8 cineole & 12.64 & 12.36 & 12.56 & 11.69 & 10.34 & 10.61 & 10.01 \\
\hline Terpinolene & 1.21 & 0.62 & 1.14 & 0.86 & 0.85 & 0.66 & 0.69 \\
\hline Linalool & 27.53 & 27.24 & 28.25 & 24.10 & 24.83 & 26.59 & 26.37 \\
\hline Camphor & 3.90 & 5.18 & 3.87 & -- & --- & 3.79 & 3.42 \\
\hline Borneol & 7.79 & 5.31 & 7.59 & 11.85 & 9.90 & 6.10 & 6.90 \\
\hline Terpinene-4-ol & 1.71 & 1.58 & 1.52 & 1.77 & 1.36 & 1.48 & 1.26 \\
\hline$\alpha$-Terpineol & 2.48 & 5.38 & 5.04 & 5.70 & 5.00 & 5.17 & 3.88 \\
\hline Methyl chavicole & 2.26 & 5.49 & 2.12 & 7.04 & 5.58 & 5.38 & 4.16 \\
\hline Bornyl-acetate & 1.34 & 1.47 & 1.18 & 1.57 & 1.51 & 1.84 & 2.57 \\
\hline Eugenol & 28.27 & 23.23 & 28.76 & 25.93 & 24.62 & 22.27 & 18.43 \\
\hline$\beta$-caryophyllene & 0.61 & - & 0.69 & 2.37 & 0.30 & 1.01 & 0.33 \\
\hline
\end{tabular}

\section{Total phenolic content}

The changes in phenolic content would play functional roles in the irradiation stress response of basil plants. Plants exposed to elevated $\gamma$-irradiation doses significantly increased total phenolic content, the highest content was reported for irradiated plants with $30 \mathrm{kR}$ while the lowest content was obtained under $5 \mathrm{kR}$ and control without significant variation between them especially in the second season (Fig., 3). The importance of phenol

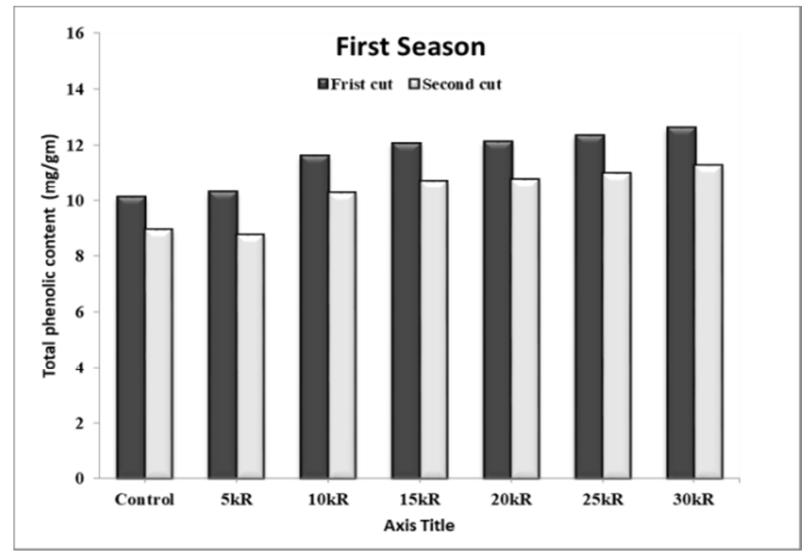

Fig. 3. Effect of various doses of gamma irradiation on total phenolic content (mg/gm) of Ocimum basilicum $\mathrm{L}$. in the two cuts of both seasons (2017/2018).

\section{CONCLUSION}

From the current investigation, it is clear that low doses of gamma rays increased germination percentage, vegetative growth, chlorophyll a, b, and yield characters of Ocimum basilicum L. On the other hand, high gamma irradiation doses significantly decreased germination percentage, vegetative growth, chlorophyll a, b, oil yield and oil components while, carotenoids and total phenolic content were increased as compared to non-irradiated plants in both growing seasons. It can be concluded that treating basil seeds by gamma rays at $10 \mathrm{kR}$ can be successfully utilized for enhancing vegetative growth and oil yield of basil plants.

\section{REFERENCES}

Aly, A.A.; R.W. Maraei and S. Ayadi (2018).Some biochemical changes in two egyptian bread wheat cultivars in response to gamma irradiation and salt stress. Bulg. J. Agric. Sci.,24(1):50-59.

Bhala, V.P. and R.C. Verma (2018).Gamma rays induced chromosomal aberrations in tomato (Solanum lycopersicum L .). Chromosome Bot., 12 (4):86-90. evaluation is due to the phenolic compounds perform significant physiological and ecological roles, being participated in resistance to various types of stresses (Masoud et al., 2018). Increases in total phenolic content is considered a common response for high irradiation doses which were earlier confirmed by the findings of several workers in different plants ( Said-al Ahl et al., 2015, Masoud et al., 2018 and Suneetha et al., 2018).

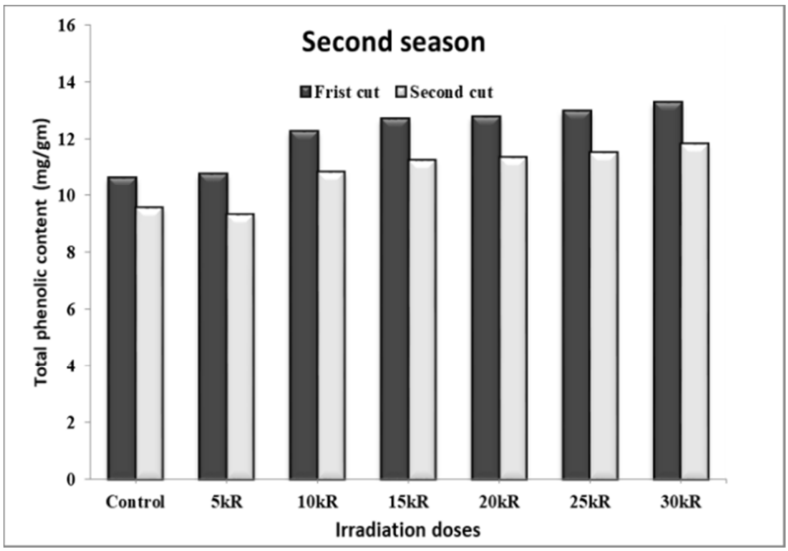

Bhat, I.A.; U.J. Pandit; I.A. Sheikh and Z.U. Hassan (2016).Physical and chemical mutagenesis in Linum usitatissimum L. to induce variability in seed germination, survival, and growth rate traits. Curr. Bot., 7:28-32.

Bhosale, R. and A. More (2014).Effect of gamma radiation on seed germination, seedling height and seedling injury in Withania somnifera, ( L.) Dunal . Int. J. Life Sci.,2(3):226-228.

Dai, J. and R.J. Mumper (2010).Plant phenolics: extraction, analysis and their antioxidant and anticancer properties. Molecules., 15:7313-7352.

Darrah, H.H. (1988).Cultivated Basils. Buckeye Printing Company, Independence, MO.

Datta, S.K. (2009).“A report on 36 years of practical work on crop improvement through induced mutagenesis."in: Induced Plant Mutations in the Genomics Era,Shu, Q.Y. (Ed).Food and Agriculture Organization of the United Nations, Rome. pp.253-256.

Deshpande, R.S. and H.P. Tipnis (1977).Insecticidal activity of Ocimum basilicum Linn. Pesticides., 11:1-12. 
Diehl, J.F. (2002).Food irradiation past, present and future. Radiat. Phys. Chem.,63:211-215.

Farkas, J. and C. Mohácsi-Farkas (2011).History and future of food irradiation. Trends Food Sci. Technol.,22(2-3):121-126.

Hameed, A.; T.M. Shah; B.M. Atta; M.A. Haq and H. Sayed (2008).Gamma irradiation effects on seed germination and growth, protein content, peroxidase and protease activity, lipid peroxidation in desi and kabuli chickpea. Pak. J. Bot.,40 (3): 1033-1041.

Hamideldin, N. and N.E. Eliwa (2015).Gamma irradiation effect on growth, physiological and molecular aspects of mustard plant. Am. J. Agric. Sci.,2(4) : 164-170.

Jindal, K.K. and R.N. Singh (1975).Phenolic content in male and female Carica papaya: a possible physiological marker for sex identification of vegetative seedlings. Physiol. Plant.,33(1):104-107.

Juliani, H.R. and J.E. Simon (2002).“Antioxidant activity of basil.”in: Janic J. and A.Whipkey (eds.), Trends in New Crops and New Uses.ASHS Press: Alexandria, VA, pp.575-579.

Khan, W.M.; S.Z. Shah; M.S. Khan; Z.U. Islam; S. Ali; F. Hussain; M. Irshad and M. Zahid (2014).Effects of gamma radiations on some morphological and biochemical characteristics of Brassica napus L . (variety Altex). Int. J. Biosci.,4(10):36-41.

Lichtenthaler, H.K. and C. Buschmann (2001). Chlorophylls and carotenoids: measurement and characterization by UV-VIS spectroscopy. Curr. Protoc. food Anal. Chem. F4.2.1- F4.2.6.

Masoud, M.; M.A. Zayed; D. Gad and M.A. Elhaak (2018).Effect of gamma irradiation on some metabolites of Cichorium pumilum Jacq. Egypt. J. Exp. Biol.,14(1):153-159.

Mokobia, C.E. and O. Anomohanran (2005).The effect of gamma irradiation on the germination and growth of certain Nigerian agricultural crops. J. Radiol. Prot.,25(2):181-188.

Page, A.L.; R.H. Miller and D.R. Keeney (1982).Methods of Soil Analysis -Chemical and Microbiological Properties. Madison, Wisconsin.

Pharmacopoeia, B. (1963).Determination of Volatile Oil in Drugs.london.

Pimonrat, P. and C. Yi (2017).Effect of gamma irradiation and salt stress on survival rate and growth of hom thong banana. Int. J. Agric. Technol.,13(7.3):23872391 .
Said-al Ahl, H.A.H.; A.M.Z. Sarhan; A.D.M. Abou Dahab; E.-S.N. Abou-Zeid; M.S. Ali and N.Y. Naguib (2015).Bio-fertilizer and gamma radiation influencing flavonoids content at different parts of dill herb. Int. J. Life Sci.\& Eng., 1(4):145-149.

Shala, A.Y. and M.A. Mahmoud (2018).Influence of glycinebetaine on water stress tolerance of Hibiscus sabdariffa L. plant. J. Plant Prod. Mansoura Univ.,9(12):981-988.

Simon, J.E.; J. Quinn and R.G. Murray (1990)."Basil: a source of essential oils."in: Janick J. and J.E. Simon (eds.), Advances in New Crops.Timber Press: Portland, OR. pp. 484-489.

Snedecor, G.W. and W.G. Cochran (1980).Statistical Methods, Seventh Edition (Ames, IA: The Iowa State University Press).

Srivastava, A.K. (1980).French basil and its cultivation in India. Cent. Inst. Med. Aromat. Plants, Lucknow,: $1-15$.

Stoeva, N. (2002).Physiological effects of the synthetic growth regulator thidiazurol (drop) on gammairradiated stress in peas plants (Pissum sativum L). J. Cent. Eur. Agric.,3(4).:293-300.

Suneetha, S.; B.T. Priya; M.R. Shekar; S. Sadarunnisa and P. Latha (2018). Effect of gamma rays treatments on percentage germination, morphological variation and chlorophyll mutation in musk okra (Abelmoschus moschatus L .). Int. J. Curr. Microbiol. Appl. Sci.(6):2875-2884.

Vardhan, P.V. and L.I. Shukla (2017).Gamma irradiation of medicinally important plants and the enhancement of secondary metabolite production. Int. J. Radiat. Biol.,93(9):967-979.

Verma, A.K.; S. Sharma; R.K. Kakani; R.D. Meena and S. Choudhary (2017).Gamma radiation effects seed germination , plant growth and yield attributing characters of fennel (Foeniculum vulgare Mill.). Int. J. Curr. Microbiol. Appl. Sci.,6(5):2448-2458.

Villavicencio, A.L.C.H.; S.A. Heleno; R.C. Calhelha; C. Santos-Buelga; L. Barros and I.C.F.R. Ferreira (2018).The influence of electron beam radiation in the nutritional value, chemical composition and bioactivities of edible flowers of Bauhinia variegata $\mathrm{L}$. var. candida alba Buch.-Ham from Brazil. Food Chem.,241:163-170.

Wi, S.G.; B.Y. Chung; J.-S. Kim; J.-H. Kim; M.-H. Baek; J.-W. Lee and Y.S. Kim (2007).Effects of gamma irradiation on morphological changes and biological responses in plants. Micron.,38(6):553564.

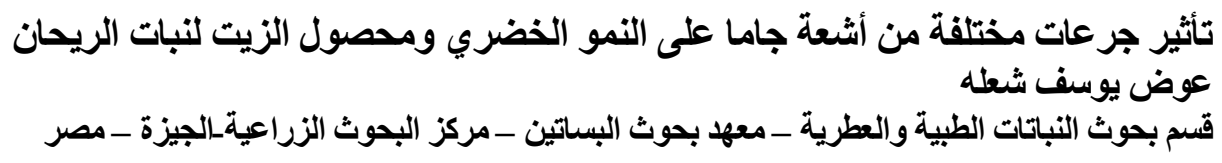

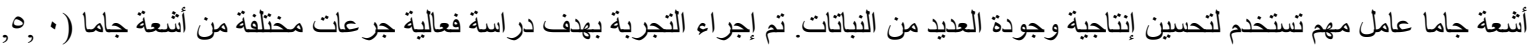

• •

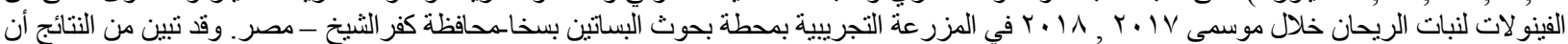

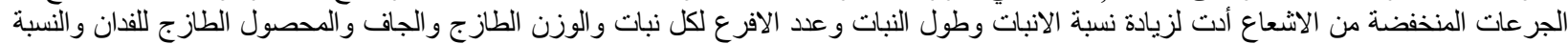

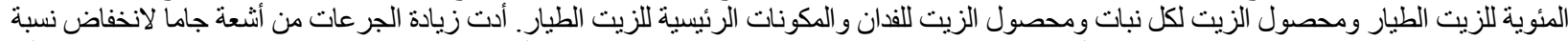

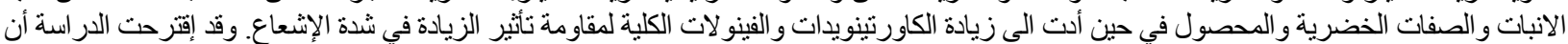

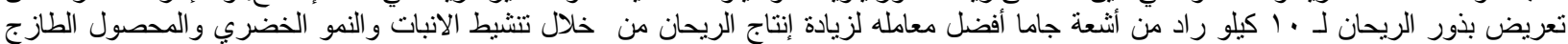

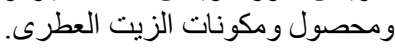

